\title{
RECONSIDERATION FOR A STUDY OF THE EFFECT OF CHLORIDE BINDING ON SERVICE LIFE PREDICTIONS
}

\author{
Ming-Te Liang \\ Department of Civil Engineering, China University of Science and Technology, Taipei, Taiwan, R.O.C., \\ mtliang@cc.cust.edu.tw \\ Ran Huang \\ Department of Harbor and River Engineering, National Taiwan Ocean University, Keelung, Taiwan, R.O.C. \\ Hao-Yuan Jheng \\ Department of Harbor and River Engineering, National Taiwan Ocean University, Keelung, Taiwan, R.O.C.
}

Follow this and additional works at: https://jmstt.ntou.edu.tw/journal

Part of the Engineering Commons

\section{Recommended Citation}

Liang, Ming-Te; Huang, Ran; and Jheng, Hao-Yuan (2011) "RECONSIDERATION FOR A STUDY OF THE EFFECT OF CHLORIDE BINDING ON SERVICE LIFE PREDICTIONS," Journal of Marine Science and Technology. Vol. 19: Iss. 5, Article 9.

DOI: $10.51400 / 2709-6998.2167$

Available at: https://jmstt.ntou.edu.tw/journal/vol19/iss5/9

This Research Article is brought to you for free and open access by Journal of Marine Science and Technology. It has been accepted for inclusion in Journal of Marine Science and Technology by an authorized editor of Journal of Marine Science and Technology. 


\section{RECONSIDERATION FOR A STUDY OF THE EFFECT OF CHLORIDE BINDING ON SERVICE LIFE PREDICTIONS}

Acknowledgements

The authors gratefully acknowledge the support provided for this research by the National Science Council, Republic of China, under contract No. NSC96-2221-E-157-002. 


\title{
RECONSIDERATION FOR A STUDY OF THE EFFECT OF CHLORIDE BINDING ON SERVICE LIFE PREDICTIONS
}

\author{
Ming-Te Liang*, Ran Huang**, and Hao-Yuan Jheng**
}

Key words: bound chloride, chloride binding, diffusion, free chloride, modeling, service life prediction, total chloride.

\section{ABSTRACT}

The major purpose of this paper is to use Kirchhoff's transformation associated with Laplace's transformation methods to obtain the analytical solution of the modified Fick's second law of nonlinear diffusion equation with initial and boundary conditions provided by Martín-Pérez et al. [A study of the effect of chloride binding on service life predictions. Cement and Concrete Research 2000; 30 (8): 1215-1223]. Based on experimented data and four kinds of chloride binding isotherm, i.e., no, linear, Langmuir, and Freundlich binding, results of free and total chloride concentration profiles calculated from the analytical solution are presented for a concrete structure suffered from two different exposure conditions: submerged in seawater and exposed to deicing salts during 6 months, 5 years, 30 years and 50 years, respectively. The difference between the analytical solution and the approximate solution obtained by Martín-Pérez et al. used finite-difference method can be represented by percentage error. The percentage errors of Freundlich's binding are higher than those of no binding and linear binding when both service life and concrete cover increase. The implication of answering for chloride binding in service life predictions is in detail discussed. The result of present study may offer as a critical reference of maintenance, strengthening, and demolition of concrete or reinforced concrete (RC) structures subjected to chloride-ion penetration.

\section{INTRODUCTION}

One of the principal generates of deterioration of reinforced concrete $(\mathrm{RC})$ structures is chloride-induced corrosion of the

Paper submitted 10/07/09; revised 06/07/10; accepted 06/11/10. Author for correspondence: Ming-Te Liang (e-mail: mtliang@cc.cust.edu.tw).

*Department of Civil Engineering, China University of Science and Technology, Taipei, Taiwan, R.O.C.

**Department of Harbor and River Engineering, National Taiwan Ocean University, Keelung, Taiwan, R.O.C. steel reinforcement. Chloride-induced corrosion of steel reinforcement in $\mathrm{RC}$ exposed to marine environments and deicing salts has become an important issue of primacy concern for RC projects, such as bridge decks, parking garages, and marine structures. Corrosion damage in these structures is generally proved by rust-staining of the steel surface and by cracking and spalling of the concrete cover owing to the expansion of the corrosion products. It also can result in future structural distress owing to the loss of the cross-sectional area of steel reinforcement and the loss of bond along the steel-concrete interface [16].

The formation of a layer of iron-oxide $\left(\gamma-\mathrm{Fe}_{2} \mathrm{O}_{3}\right)$ around the steel in concrete is usually the concrete with the highly alkaline medium provided by the cement matrix in concrete. This iron-oxide sustains the steel reinforcement in a passive state which the corrosion rate is in notable low. Nevertheless, when an enough amount of chloride. encompasses the steel reinforcement, a pitted breakdown of the passivating layer transpires and the corrosion process is then initiated. Chlorides in concrete can be either dissolved in the pore solution (free chloride) or chemically bound and physically absorbed to the cement hydrates and their surfaces (bound chlorides). Because the free chloride dissolved in the pore solution continue to ingress into the concrete cover, mere it is obliged to initiate the process of corrosion $[2-4,8,9,11,14,15,17,18$, 20, 21, 24-27, 29-31, 33].

In efforts to control the significant problem of the penetration of chloride ions into concrete surfaces to steel reinforcement leading to corrosion, many innovations in concrete technology have been made. One of these technologies consists of the development of service life prediction models. The effect of chloride binding on service life predication was studied by Martín-Pérez et al. [16]. They assumed that the concrete cover is fully saturated. They derived a modified Fick's second law of nonlinear diffusion equation for predicting the service lives of concrete components. They also pointed out that the governing partial differential equation (PDE) cannot be solved without the use of numerical methods because of the dependency of diffusivity on free chloride for non-linear binding isotherms. They did not offer the results of the Langmuir binding isotherm. The work presented here focuses on deriving the analytical solution of the governing PDE developed by Martín- 
Pérez et al. [16]. Both the free and total chloride concentration profiles calculated from the analytical solution of no, linear, Langmuir, and Freundlich binding isotherms are provided. The difference between the analytical solution and the approximate solution obtained by Martín-Pérez et al. [16] applied finite-difference method can be expressed by percentage error and will be discussed. The result of present study can be provided as an important reference of maintenance, strengthening, or demolition to existing concrete or RC structures laden in chloride environment.

\section{PARTIAL DIFFERENTIAL EQUATION OF FREE CHLORIDE DIFFUSION}

Martín-Pérez et al. [16] studied the effect of chloride binding on ionic diffusion under the assumption that the concrete cover is fully saturated. They represented the relations between total, bound, and free chloride concentrations in concrete as

$$
C_{t}=C_{b}+\omega_{\mathrm{e}} \cdot C_{f}\left[\mathrm{~kg} / \mathrm{m}^{3} \text { of concrete }\right]
$$

where $C_{t}, C_{b}$, and $C_{f}$ are the total, bound, and free chloride concentrations $\left(\mathrm{kg} / \mathrm{m}^{3}\right.$ of concrete) respectively. $\omega_{\mathrm{e}}$ is the evaporable water content $\left(\mathrm{m}^{3}\right.$ evaporable water $/ \mathrm{m}^{3}$ concrete).

By applying the principle of mass conservation to Eq. (1) and substituting into Fick's second law

$$
\frac{\partial C_{t}}{\partial t}=\frac{\partial}{\partial x}\left(D_{c} \cdot \omega_{\mathrm{e}} \cdot \frac{\partial C_{f}}{\partial x}\right)\left[\mathrm{kg} /\left(\mathrm{m}^{3} \cdot \mathrm{s}\right)\right]
$$

where $D_{c}$ is the effective diffusion coefficient $\left[\mathrm{m}^{2} / \mathrm{s}\right], x$ is the space [m], and $t$ is the time [s], the following modified Fick's second law equation with initial and boundary conditions is expressed in terms of

$$
\begin{gathered}
\frac{\partial C_{f}}{\partial t}=\frac{\partial}{\partial x}\left(D_{c}^{*} \cdot \frac{\partial C_{f}}{\partial x}\right)\left[\mathrm{kg} /\left(\mathrm{m}^{3} \cdot \mathrm{s}\right)\right] \\
C_{f}(x, 0)=0 \\
C_{f}(0, t)=C_{s} \\
C_{f}(L, t)=0
\end{gathered}
$$

with

$$
D_{c}^{*}=\frac{D_{c}}{1+\frac{1}{\omega_{\mathrm{e}}} \frac{\partial C_{b}}{\partial C_{f}}}\left[\mathrm{~m}^{2} / \mathrm{s}\right]
$$

where $D_{c}^{*}$ is the apparent diffusion coefficient $\left(\mathrm{m}^{2} / \mathrm{s}\right), \partial C_{b} / \partial C_{f}$ is the "binding capacity" of the concrete binder $\left(\mathrm{m}^{3}\right.$ of pore solution $/ \mathrm{m}^{3}$ concrete) [19], $C_{s}$ is the chloride concentration of the salt solution in contact with the outer surface $\left(\mathrm{kg} / \mathrm{m}^{3}\right.$ of solution), and $\mathrm{L}$ is the thickness of the member ( $\mathrm{mm}$ ).

Eq. (3a) is a non-linear PDE. To solve this equation, first, Kirchhoff's transformation is used to render the non-linear problem into a linear one $[5,10,13,28]$. A new variable $\psi$ is defined such that

$$
\frac{d \psi}{d C_{f}}=D_{c}^{*}\left(C_{f}\right)
$$

Eq. (4) can also be written in integral form as follows,

$$
\psi(x, t)=\int_{C_{r}}^{C_{f}} D_{c}^{*}\left(C_{f}\right) d C_{f}=K\left(C_{f}\right)
$$

Eq. (5) is called Kirchhoff's transformation [5, 10, 13, 28], where $C_{r}$ is an arbitrary reference value. In order to make a convenience of integration, we choose $C_{r}=C_{s}$. By applying the concepts of chain rule and Leibniz's rule to Eqs. (4) and (5) the following three equations can be obtained, respectively,

$$
\begin{gathered}
\frac{\partial \psi}{\partial t}=\frac{\partial \psi}{\partial C_{f}} \frac{\partial C_{f}}{\partial t}=D_{c}^{*} \frac{\partial C_{f}}{\partial t} \\
\frac{\partial \psi}{\partial x}=D_{c}^{*} \frac{\partial C_{f}}{\partial x} \\
\frac{\partial^{2} \psi}{\partial x^{2}}=\frac{\partial}{\partial x}\left(D_{c}^{*} \frac{\partial C_{f}}{\partial x}\right)
\end{gathered}
$$

Eq. (3) is multiplied by $D_{c}^{*}$ and changed as

$$
D_{c}^{*} \frac{\partial C_{t}}{\partial t}=D_{c}^{*} \frac{\partial}{\partial x}\left(D_{c}^{*} \frac{\partial C_{f}}{\partial x}\right)
$$

Substituting Eqs. (6) (8) into Eq. (9), we obtain the following linear PDE

$$
\frac{\partial \psi}{\partial t}=D_{c}^{*} \frac{\partial^{2} \psi}{\partial x^{2}}
$$

The initial and boundary conditions stated above are also transferred as

$$
\begin{gathered}
\psi(x, 0)=\int_{C_{s}}^{C_{f}=0} D_{c}^{*}\left(C_{f}\right) d C_{f}=K\left(C_{f}=0\right)=K_{0} \\
\psi(0, t)=\int_{C_{s}}^{C_{s}} D_{c}^{*}\left(C_{f}\right) d C_{f}=K\left(C_{s}\right)=0
\end{gathered}
$$




$$
\psi(L, t)=K_{0}
$$

The method of Laplace transformation is used to solve Eq. (10). The definition of Laplace transformation of $\psi(x, t)$ [22] is

$$
\Omega(x, s)=L[\psi(x, t)]=\int_{0}^{\infty} \psi(x, t) e^{-s t} d t
$$

Thus, the Laplace transformation of Eq. (10) is given as follows

$$
\Omega(x, s)=\frac{K_{0}}{s}-K_{0} \frac{e^{-\sqrt{\frac{s}{D_{c}^{*}}} x}}{s}
$$

The inverse Laplace transformation for the first term in Eq. (12) equals to $K_{0}$ and the second term [6] is given as

$$
L^{-1}\left\{\frac{e^{-\sqrt{\frac{s}{D_{c}^{*}}} x}}{s}\right\}=\operatorname{erfc}\left\{\frac{x}{2 \sqrt{D_{c}^{*} t}}\right\}=1-\operatorname{erf}\left\{\frac{x}{2 \sqrt{D_{c}^{*} t}}\right\}
$$

where erf is the error function and erfc is the complementary error function. Thus, by taking the inverse Laplace transformation on both sides of Eq. (12),we have

$$
\psi(x, t)=K_{0} \operatorname{erfc}\left(\frac{x}{2 \sqrt{D_{c}^{*} t}}\right)
$$

The substitution of Eqs. (5) and (10b) into Eq. (14) yields

$$
\frac{\int_{C_{\mathrm{s}}}^{C_{f}} D_{c}^{*}\left(C_{f}\right) d C_{f}}{\int_{C_{\mathrm{s}}}^{0} D_{c}^{*}\left(C_{f}\right) d C_{f}}=\operatorname{erfc}\left(\frac{x}{\sqrt{4 D_{c}^{*} t}}\right)
$$

Eq. (15) is the exact or analytical solution of Eq. (3). This equation provides the relationship among apparent diffusion coefficient $D_{c}^{*}$, free chloride concentration $C_{f}$, and penetration depth $x$ and time $t$. The left side of Eq. (15) is purely the area ratio between areas under the $D_{c}^{*}-C_{f}$ curve from $C_{s}$ to $C_{f}$ and $C_{s}$ to 0 , respectively (Fig. 1 ).

\section{CHLORIDE BINDING ISOTHERMS}

Chloride binding isotherms present the relationships between free and bound chloride in concrete at a given temperature. They are dependent on the components making up that system such as $\mathrm{C}_{3} \mathrm{~A}$ concrete, $\mathrm{pH}$ of the pore solutions, and supplementary cementing materials. They are also dependent on the environmental conditions such as temperature and relative humidity.

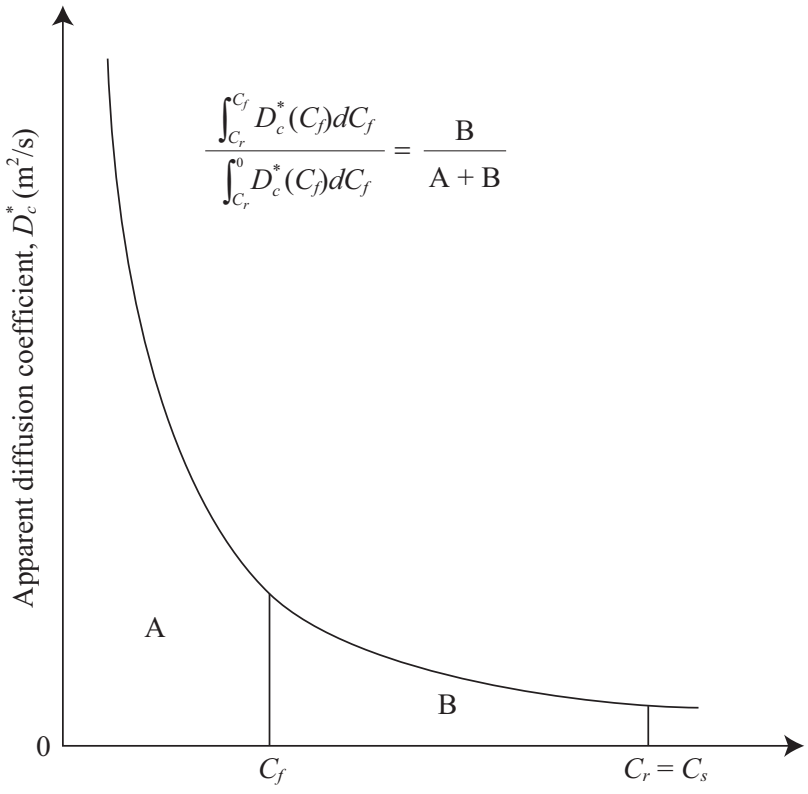

Free chloride concentration, $C_{f}\left(\mathrm{~kg} / \mathrm{m}^{3}\right)$

Fig. 1. Relationship between $D_{c}^{*}$ and $C_{f}$.

\section{Experimental Data}

Tang and Nilsson [30] developed an experimental procedure for obtaining the chloride binding data. Their experimental procedures are cited by Martín-Pérez et al. [16]. The experimental data obtained by Martín-Pérez et al. [16] will be used in this study.

\section{Mathematical Models}

Eq. (3e) describes the apparent diffusion coefficient and the corresponding binding capacity. Four theoretical curves used in the literature to express chloride binding in concrete are reviewed in the following [16]:

No binding

$$
C_{b}=0, \frac{\partial C_{b}}{\partial C_{f}}=0, D_{c}^{*}=D_{c}
$$

Linear binding

$$
C_{b}=\alpha C_{f}, \frac{\partial C_{b}}{\partial C_{f}}=\alpha, D_{c}^{*}=\frac{D_{c}}{1+\frac{\alpha}{\omega_{\mathrm{e}}}}
$$

where $\alpha$ is the slope of the line.

Langmuir binding

$C_{b}=\frac{\alpha C_{f}}{1+\beta C_{f}}, \frac{\partial C_{b}}{\partial C_{f}}=\frac{\alpha}{\left(1+\beta C_{f}\right)^{2}}, D_{c}^{*}=\frac{D_{c}}{1+\frac{\alpha}{\omega_{\mathrm{e}}\left(1+\beta C_{f}\right)^{2}}}$ 


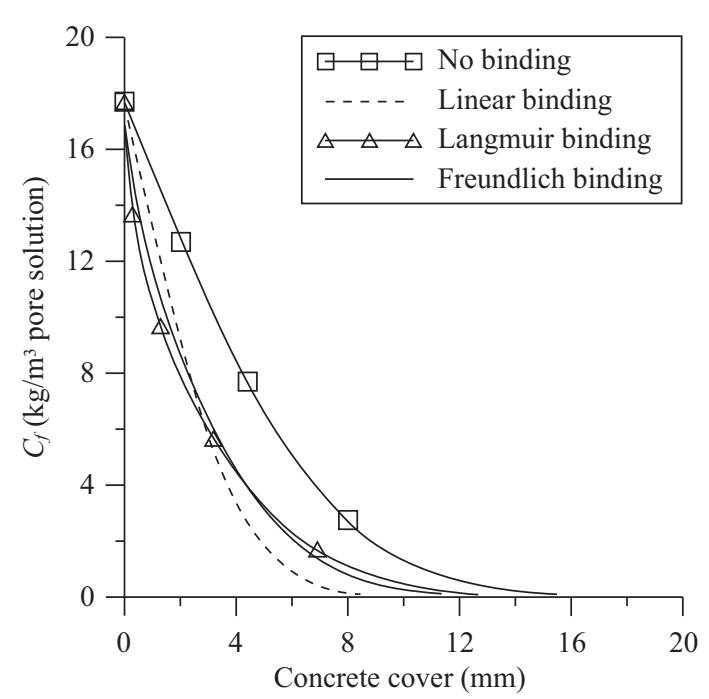

(a) 6 months

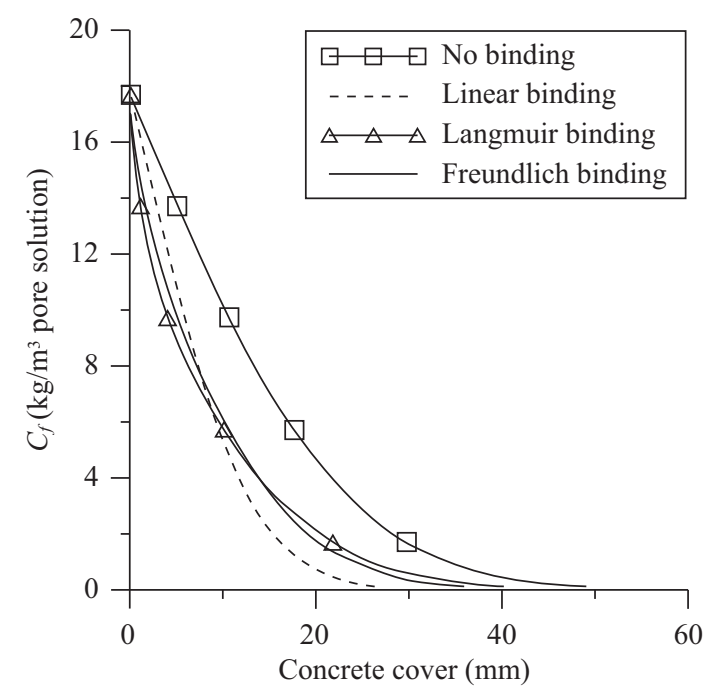

(b) 5 years

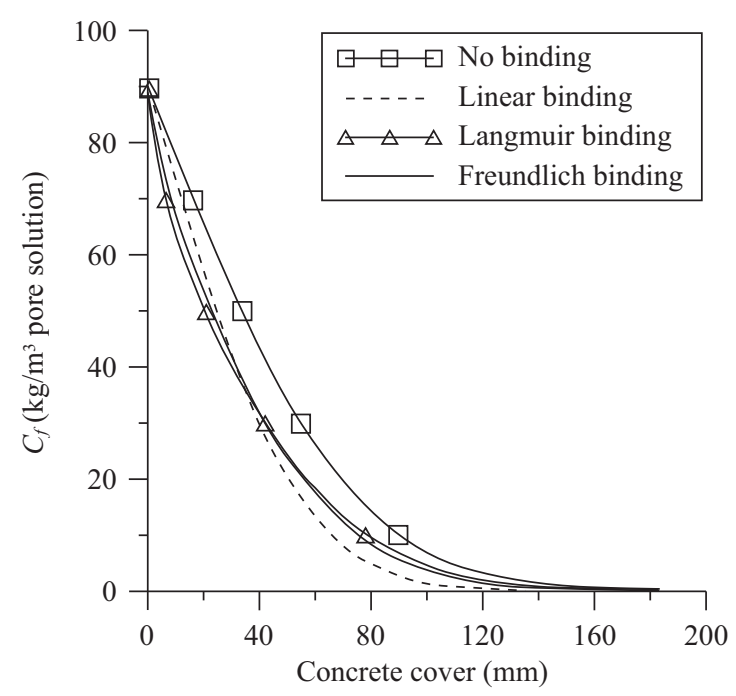

(c) 50 years

Fig. 2. Free chloride concentration profiles at (a) 6 months, (b) 5 years, and (c) 50 years for $0.5 \mathrm{M}$ exposure conditions. where $\alpha$ and $\beta$ are the binding constants which vary according to the concrete binder composition.

Freundlich binding

$$
C_{b}=\alpha C_{f}^{\beta}, \frac{\partial C_{b}}{\partial C_{f}}=\alpha \beta C_{f}^{\beta-1}, D_{c}^{*}=\frac{D_{c}}{1+\frac{1}{\omega_{\mathrm{e}}} \alpha \beta C_{f}^{\beta-1}}
$$

\section{ANALYTICAL RESULTS}

Martín-Pérez et al. [16] obtained chloride binding isotherms for two cement pastes with $w / \mathrm{cm}=0.3$ and $40 \%$ slag and fly ash replacement levels, respectively, as shown in Fig. 1 in Ref. [16]. Based on Fig. 1 mentioned early and assumed that $\omega_{e}=$ $8 \%, C_{b}=450 \mathrm{~kg} / \mathrm{m}^{3}\left(\mathrm{~kg} / \mathrm{m}^{3}\right.$ of concrete $)$ and $C_{s}=0.5 \mathrm{M}$ and $C_{s}=2.5 \mathrm{M}$ and used Eqs. (17), (18) and (19), they obtained the values of $\alpha$ and $\beta$ from regression analysis used least-squares method for the linear, Langmuir and Freundlich isotherms as presented in Fig. 2 in Ref. [16]. Based on Fig. 2 stated above and proposed that $D_{c}=1.0 \times 10^{-12} \mathrm{~m}^{2} / \mathrm{s}$ and used Eqs. (16)-(19), they gained the ratio of $D_{c}^{*} / D_{c}$ versus free chloride as displayed in Fig. 3 in Ref. [16].

To investigate the effect of the binding isotherm nature on the chloride concentration profiles, the proposed method was carried out using a commercial computer package named "Mathematica" [32]. The four mathematical models of chloride binding isotherm were analyzed .The input parameters required to perform the proposed method are $\mathrm{L}=200 \mathrm{~mm}, \omega_{e}=$ $8 \%, C_{b}=450 \mathrm{~kg} / \mathrm{m}^{3}$ of concrete, $D_{c}=1.0 \times 10^{-12} \mathrm{~m}^{2} / \mathrm{s}, C_{s}=0.5$ $\mathrm{M}$ and $C_{s}=2.5 \mathrm{M}$. It is noteworthy to point out that $C s=0.5$ M simulates complete submersion in sea water while $C_{s}=2.5$ $\mathrm{M}$ simulates marine structures in the splash zone or bridge decks exposed to de-icing salts. We may use Eq. (15) to obtain the free chloride concentration profiles. According to the free chloride concentration profiles and using Eq. (1), we may obtain the total chloride concentration profiles.

The free and total chloride profiles calculated are illustrated in Figs. 2 and 3 for $C_{s}=0.5 \mathrm{M}$ and in Figs. 4 and 5 for $C_{s}=2.5$ $\mathrm{M}$, respectively. The chloride concentration profiles are depicted after an exposure period of 6 months, 5 years, and 50 years and after an exposure period of 6 months, 5 years, and 30 years for the $0.5 \mathrm{M}$ and $2.5 \mathrm{M}$ surface conditions, respectively. Considering the Figs. 2 and 4, the $C_{f}$ values of no binding is larger than the other binding isotherms at any depth of concrete cover. The $C_{f}$ values of nonlinear binding are lower than the linear one when the depths of concrete cover are less than 2.43, 7.14, and $33.13 \mathrm{~mm}$ at service lives 6 months, 5 years, and 50 years for $C_{s}=0.5 \mathrm{M}$ (Fig. 2) and when the depths of concrete cover are less than $3.43,11.43$, and $26.67 \mathrm{~mm}$ at service lives 6 months, 5 years and 30 years for $C_{s}=2.5 \mathrm{M}$ (Fig. 4), respectively, Nevertheless, the $C_{f}$ values of nonlinear binding are larger than the linear one when the depths of concrete cover are larger than $2.43,7.14$, and 33.13 at service lives 6 months, 5 years, and 50 years for $C_{s}=0.5 \mathrm{M}$ (Fig. 2) 


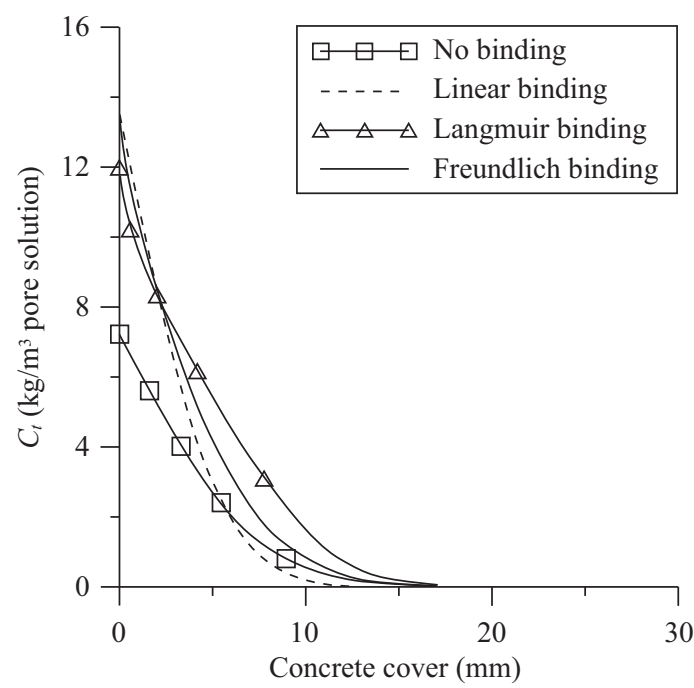

(a) 6 months

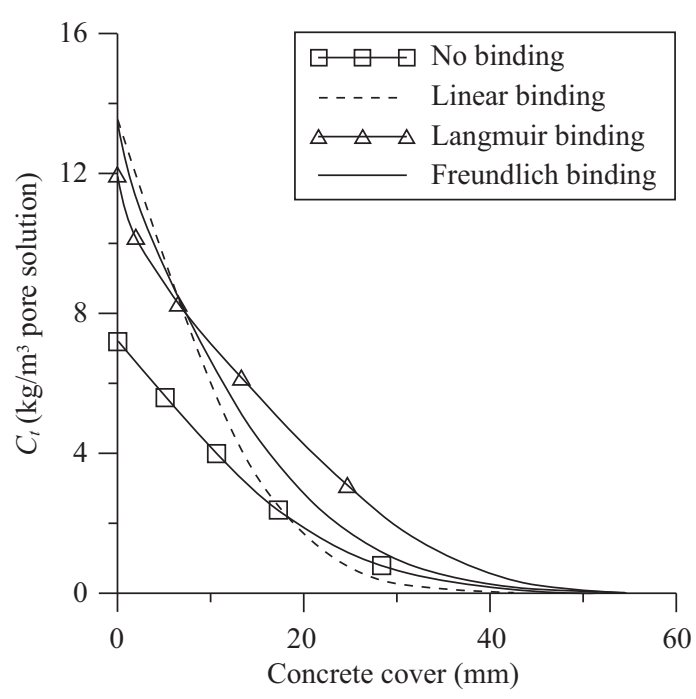

(b) 5 years

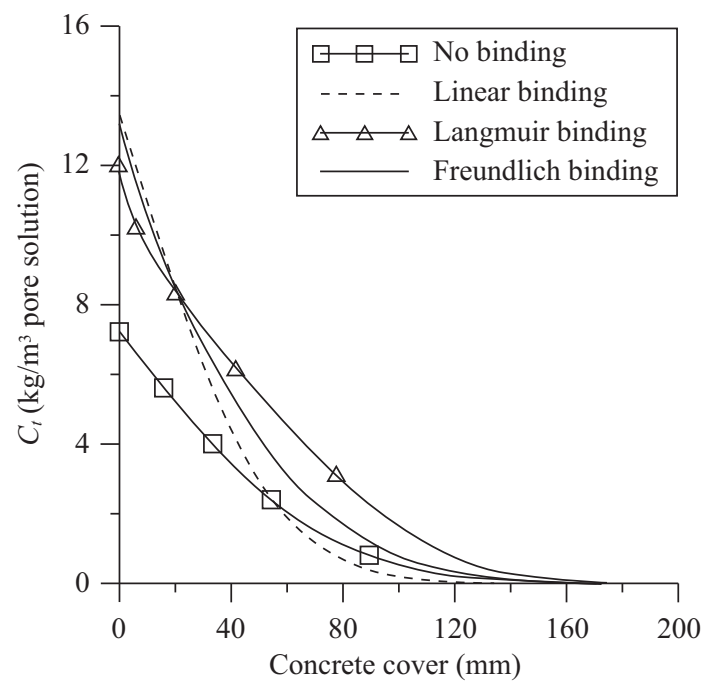

(c) 50 years

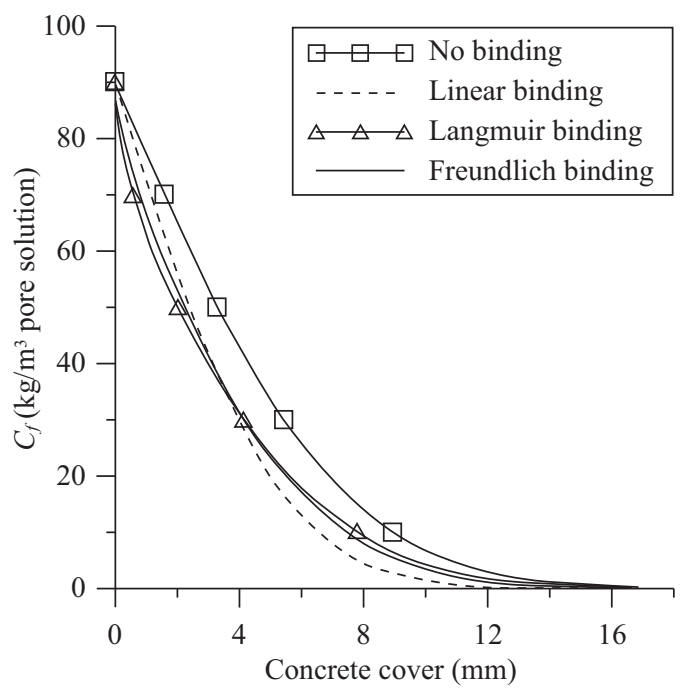

(a) 6 months

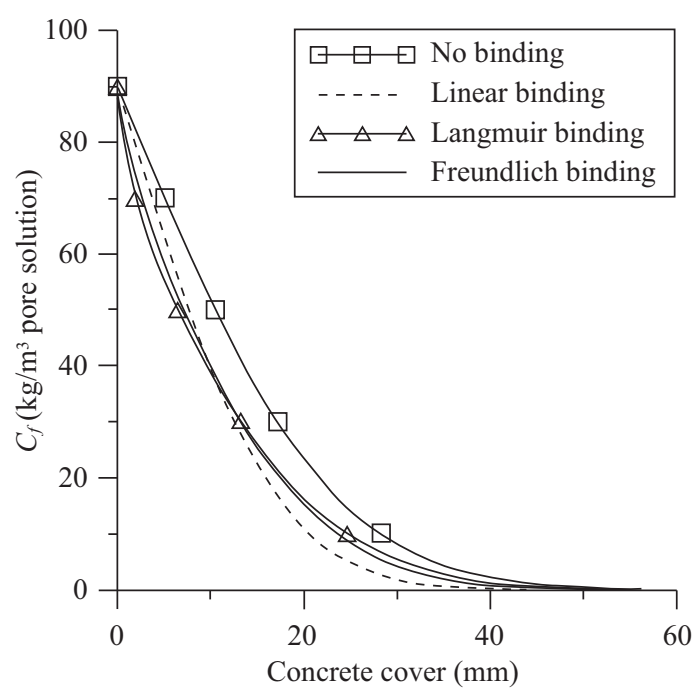

(b) 5 years

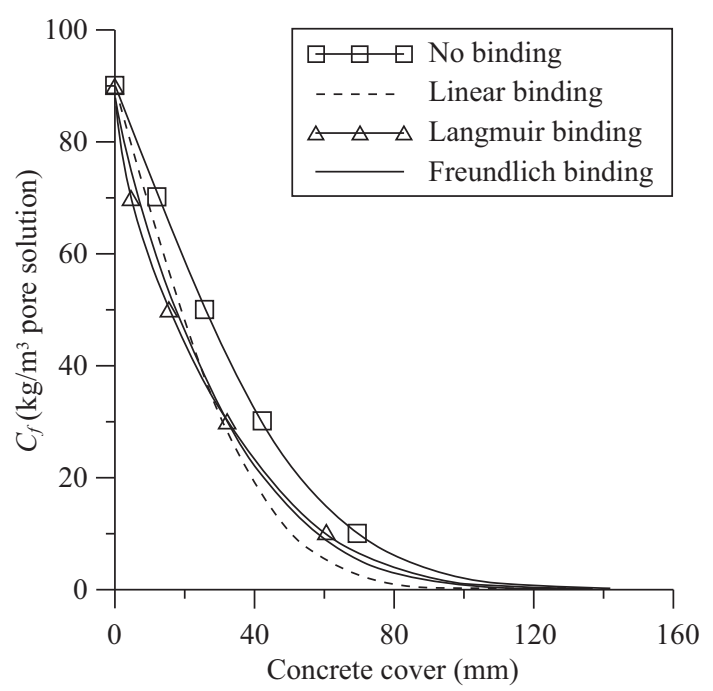

(c) 30 years

Fig. 3. Total chloride concentration profiles at (a) 6 months, (b) 5 years, and (c) 50 years for $0.5 \mathrm{M}$ exposure conditions.

Fig. 4. Free chloride concentration profiles at (a) 6 months, (b) 5 years, and (c) 30 years for $2.5 \mathrm{M}$ exposure conditions. 
and when the depths of concrete cover are larger than 3.43 , 11.43 , and $26.67 \mathrm{~mm}$ at service lives 6 months, 5 years and 30 years for $C_{s}=2.5 \mathrm{M}$ (Fig. 4). These differences become more obvious at greater concrete depths as the exposure time increases (Figs. 2(c) and 4(c)).

The distinction in configuration of the total chloride profiles in agreement with no binding, linear binding, and nonlinear binding leads to the dependency of the respective binding capacities on the level of free chloride ions. This deviation is more remarkable at low chloride concentration, where the binding capacity of the non-linear relationship is higher and more perceptive to the variety in concentration of free chlorides (see Fig. 3 in the Ref. [16]). It is noteworthy to point out that different values of $C_{f}$ (see Eq. (1)) at the surface have the different binding relations in spite of the fact that external solution $C_{s}$ has the same for the four cases (Figs. 3 and 5). From Fig. 2 in the Ref. [16] we know that the linear relationship leads to in a higher amount of bound chloride at the surface compared to that of the nonlinear relationships for both of the external solutions $C_{s}=0.5 \mathrm{M}$ and $C_{s}=2.5 \mathrm{M}$, respectively. This is due to the higher binding capacity of linear isotherms at the high levels of concentration of free chlorides.

Now examining the Figs. 3 and 5, the $C_{t}$ values of nonlinear binding are higher than the linear one when the depths of the concrete cover are larger than $2.19,6.67$, and $21.54 \mathrm{~mm}$ at service lives 6 months, 5 years, and 50 years for $C_{s}=0.5 \mathrm{M}$ (Fig. 3) and when the depths of concrete cover are larger than 2.14, 6.5, and $16 \mathrm{~mm}$ at service lives 6 months, 5 years, and 30 years for $C_{s}=2.5 \mathrm{M}$ (Fig. 5), respectively. The profiles of $C_{t}$ for non-linear binding are also higher than the one without binding. This puts emphasis on the significance of defining the threshold concentration value in terms of free or total chlorides. It appears to be more suitable to define the threshold concentration value in terms of free chlorides because these are the ones that penetrate into the concrete cover and initiate corrosion. Figs. 3 and 5 summarize the total chloride profiles and may be misleading in this regard. Higher profiles herein express more chloride ions being bound along diffusion path. Nevertheless, Glass and Buenfeld [12] pointed out that weakly bound chloride may be released into the pore solution and may present a significant corrosion risk.

To obtain service life prediction, we assume that the service life of a RC structure suffered from chloride penetration corresponds to the period until reinforcing steel bar depassivation. Glass and Buenfeld [12] suggested that free chloride threshold concentration used was $0.09 \%$ by mass of cementitious material. The $0.09 \%$ by mass corresponds to $C_{f}=5.0 \mathrm{~kg} / \mathrm{m}^{3}$ of pore solution based on $C_{b}=450 \mathrm{~kg} / \mathrm{m}^{3}$ and $\omega_{e}=8 \%$. Using Eq. (15), the resulting service life estimates for the different binding isotherm shown in Fig. 2 in Ref. [16] and different concrete covers $(\mathrm{L}=40$ and $60 \mathrm{~mm})$ for the two different exposure conditions $\left(C_{s}=0.5\right.$ and $2.5 \mathrm{M}$, respectively) are shown in Fig. 6 . It is very remarkable that the phenomenon of the binding relation has a significant effect on the results. These display a $238 \%, 177 \%$, and $166 \%$ increase in time to reinforcing steel

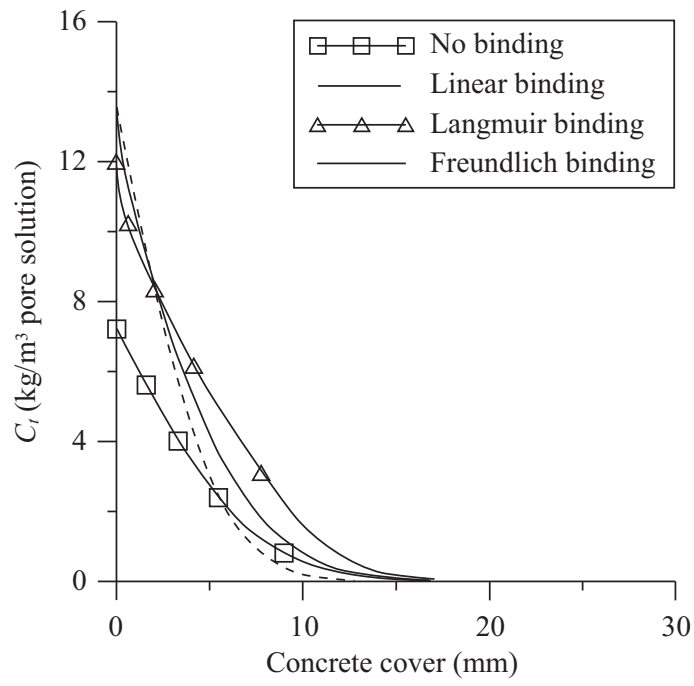

(a) 6 months

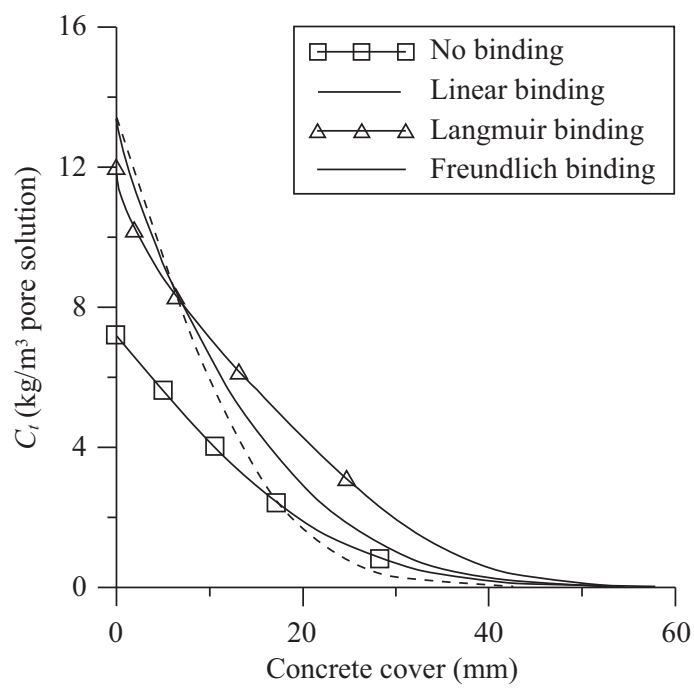

(b) 5 years

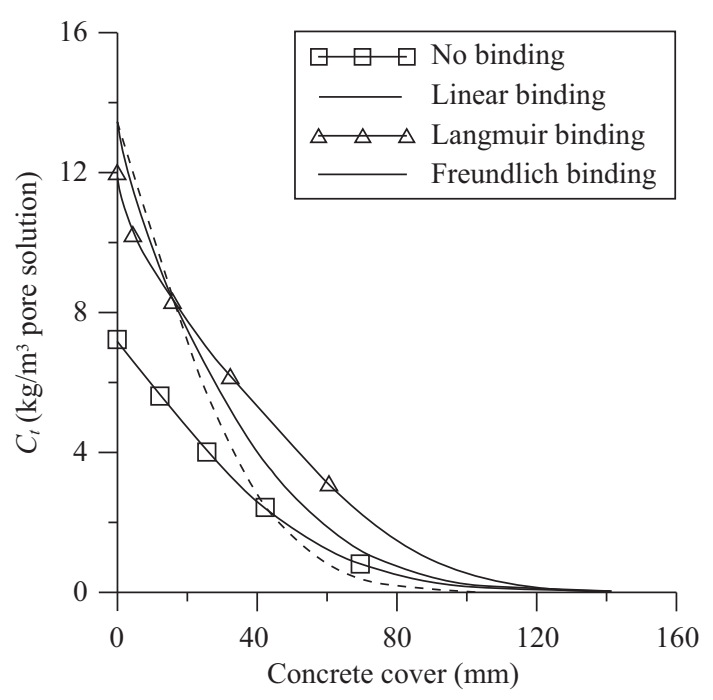

(c) 30 years

Fig. 5. Total chloride concentration profiles at (a) 6 months, (b) 5 years, and (c) 30 years for $2.5 \mathrm{M}$ exposure conditions. 


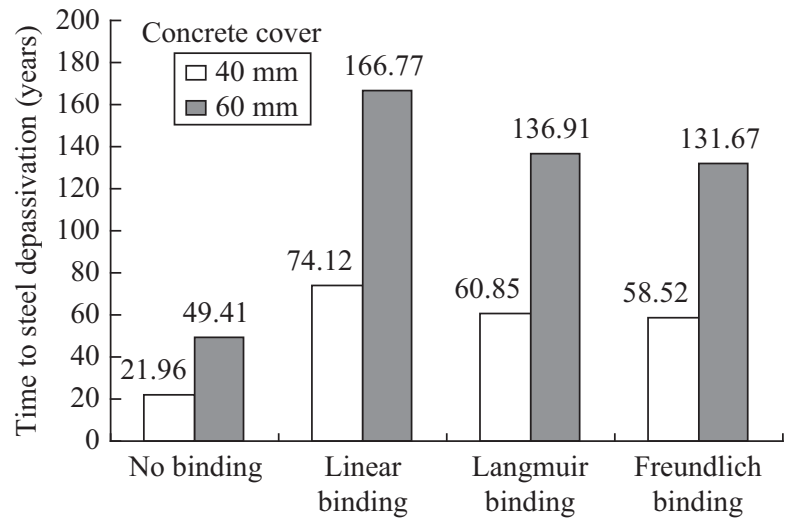

(a) $C_{s}=0.5 \mathrm{M}$

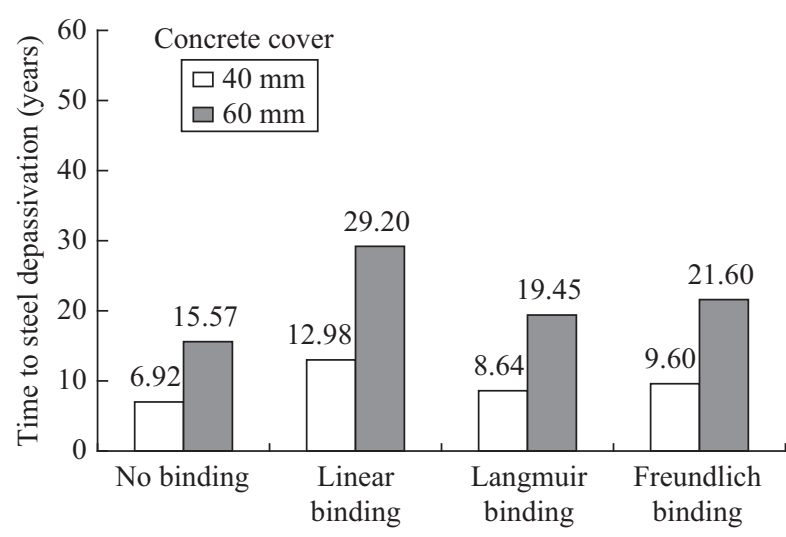

(b) $C_{s}=2.5 \mathrm{M}$

Fig. 6. Service life predictions for the different binding isotherms and different concrete covers assuming a threshold value of $0.09 \%$ by mass of binder $\left(5.0 \mathrm{~kg} / \mathrm{m}^{3}\right.$ of pore solution) and considering two different exposure conditions : (a) $C_{s}=0.5 \mathrm{M}$ and (b) $C_{s}=2.5 \mathrm{M}$.

bar depassivation for $C_{s}=0.5 \mathrm{M}$, and a $87 \%, 25 \%$, and $39 \%$ increase for $C_{s}=2.5 \mathrm{M}$ when linear, Langmuir, and Freundlich binding are taken into account, respectively. The relative increase in time to initiation corrosion is less pronounced for the higher surface concentration case because the ratio of boundto-free chlorides at high levels of chloride concentrations is smaller. When these service life predictions can serve to compare the performance of different cementitious systems with given binding properties and suffered from the same conditions, the prediction of the time to corrosion of a specific concrete structure should also consider the simultaneous effect of other crucial factors such as temperature, relative humidity, diffusivity time and space dependency, and capillary absorption to obtain the accurate result.

\section{DISCUSSION}

Eq. (3a) is a modified Fick's second law of diffusion in one-dimension and is a nonlinear PDE. In this conjunction it should be stated that Crank [7] correctly describes in his preface: "When we come to systems in which the diffusion coefficient is not constant but variable, and for the most part this means concentration dependent, we find that strictly formal mathematical solution no longer exist." Infelicitously this phrase may be misexplained so that we would believe that the problem cannot be solved mathematically. Now we know that it can. There do exist very old and almost forgotten numerical methods such as iteration methods which solve this problem mathematically, nevertheless it must be allowed that they generally demand the use of computer programs which did not exist when Crank [7] wrote his book. This concept is pointed out by Poulsen and Mejlbro [23].

Martín-Pérez et al. [16] stated that the governing PDE given by Eq. (3a) cannot be solved without the use of numerical methods due to the dependency of $D_{c}^{*}$ on $C_{f}$ for nonlinear binding isotherms. They used the finite-difference method to solve Eq. (3). In this paper, we derived the analytical solution of Eq. (3) by Kirchhoff's transformation associated with the Laplace transformation methods. Herein, we obtain the percentage errors [1] from the true value of analytical solution and the approximate value of finite-difference method as listed in Tables 1-4. Generally speaking, the percentage errors of the Freundlich binding are larger than those of no, and linear binding when both service life and concrete cover increase. It is notice that the percentage errors of the Langmuir binding cannot be shown because Martín-Pérez et al. [16] did not give its numerical results.

\section{CONCLUSIONS}

The four mathematical models of chloride binding isotherms have been reviewed. The influence of these models on the time-dependent chloride concentration profiles was studied by using of an analytical solution through Kirchhoff's transformation in connection with Laplace transformation methods to the modified Fick's second law of non-linear diffusion equation in concrete under two different exposure conditions. Based on the theoretical analysis, it was found that the concrete chloride diffusivity along the diffusion path was reduced by an amount representative of the binding capacity of the cementitious system led to in lower free chloride penetration depths, particularly when the exposure time increased. Both the free chloride concentration and calculated chloride profiles at the specified exposure conditions were affected by the binding constant of the presented models notwithstanding the quality of the fitting influenced chiefly the binding constant corresponding to the linear relation, the shock of conducting non-linear binding in the calculation of analytical solution was specially significant at low levels of free chloride for the chloride binding data employed in this investigation, without regard to exposure conditions at the concrete surface. Though the linear relation offered a better good fitting the lower the exposure conditions was, it was not able to arrest the highly nonlinear relation at this range of the employed chloride binding data. The essence of the binding relationships supposed for modeling purpose also had a remarkable shock on service life predictions. 
Table 1. Percentage errors of no, linear and Freundlich binding of free chloride concentration profiles for $0.5 \mathrm{M}$ exposure conditions.

\begin{tabular}{|c|c|c|c|c|c|c|c|c|c|c|}
\hline \multirow{3}{*}{$\begin{array}{c}\text { Service } \\
\text { life }\end{array}$} & \multirow{3}{*}{$\begin{array}{c}\text { Concrete } \\
\text { cover } \\
(\mathrm{mm})\end{array}$} & \multicolumn{9}{|c|}{$C_{f}$} \\
\hline & & \multicolumn{3}{|c|}{ No binding } & \multicolumn{3}{|c|}{ Linear binding } & \multicolumn{3}{|c|}{ Freundlich binding } \\
\hline & & $\begin{array}{c}\text { Approximate } \\
\text { value } \\
\left(\mathrm{kg} / \mathrm{m}^{3}\right)\end{array}$ & $\begin{array}{c}\text { True } \\
\text { value } \\
\left(\mathrm{kg} / \mathrm{m}^{3}\right)\end{array}$ & $\begin{array}{l}\text { Percentage } \\
\text { error } \\
(\%)\end{array}$ & $\begin{array}{c}\text { Approximate } \\
\text { value } \\
\left(\mathrm{kg} / \mathrm{m}^{3}\right)\end{array}$ & $\begin{array}{c}\text { True } \\
\text { value } \\
\left(\mathrm{kg} / \mathrm{m}^{3}\right)\end{array}$ & $\begin{array}{c}\text { Percentage } \\
\text { error } \\
(\%)\end{array}$ & $\begin{array}{c}\text { Approximate } \\
\text { value } \\
\left(\mathrm{kg} / \mathrm{m}^{3}\right)\end{array}$ & $\begin{array}{c}\text { True } \\
\text { value } \\
\left(\mathrm{kg} / \mathrm{m}^{3}\right)\end{array}$ & $\begin{array}{c}\text { Percentage } \\
\text { error } \\
(\%)\end{array}$ \\
\hline 6 month & 3 & 7.2 & 10.4 & 30.77 & 2.6 & 5.8 & 55.17 & 2.1 & 6.3 & 66.67 \\
\hline \multirow{3}{*}{5 years } & 5 & 12.6 & 13.7 & 8.03 & 8.0 & 10.7 & 25.23 & 7.7 & 9.8 & 21.43 \\
\hline & 10 & 7.7 & 10.2 & 24.51 & 2.8 & 5.3 & 47.17 & 1.2 & 5.9 & 79.66 \\
\hline & 20 & 2.6 & 4.5 & 42.22 & - & - & - & - & - & - \\
\hline \multirow{5}{*}{50 years } & 10 & 14.4 & 15.1 & 4.64 & 12.2 & 13.2 & 7.58 & 11.8 & 11.7 & 0.85 \\
\hline & 20 & 11.3 & 12.7 & 11.02 & 8.1 & 9.1 & 10.99 & 6.0 & 8.6 & 30.23 \\
\hline & 30 & 8.2 & 10.4 & 21.15 & 3.3 & 5.8 & 43.10 & 1.7 & 6.3 & 73.02 \\
\hline & 40 & 6.5 & 8.4 & 22.62 & 1.8 & 3.4 & 47.06 & - & - & - \\
\hline & 50 & 4.7 & 6.6 & 28.79 & 0.8 & 1.7 & 52.94 & - & - & - \\
\hline
\end{tabular}

Table 2. Percentage errors of no, linear and Freundlich binding of total chloride concentration profiles for $0.5 \mathrm{M}$ exposure conditions.

\begin{tabular}{|c|c|c|c|c|c|c|c|c|c|c|}
\hline \multirow{3}{*}{$\begin{array}{c}\text { Service } \\
\text { life }\end{array}$} & \multirow{3}{*}{$\begin{array}{c}\text { Concrete } \\
\text { cover } \\
(\mathrm{mm})\end{array}$} & \multicolumn{9}{|c|}{$C_{f}$} \\
\hline & & \multicolumn{3}{|c|}{ No binding } & \multicolumn{3}{|c|}{ Linear binding } & \multicolumn{3}{|c|}{ Freundlich binding } \\
\hline & & $\begin{array}{c}\text { Approximate } \\
\text { value } \\
\left(\mathrm{kg} / \mathrm{m}^{3}\right)\end{array}$ & $\begin{array}{c}\text { True } \\
\text { value } \\
\left(\mathrm{kg} / \mathrm{m}^{3}\right)\end{array}$ & $\begin{array}{c}\text { Percentage } \\
\text { error } \\
(\%)\end{array}$ & $\begin{array}{c}\text { Approximate } \\
\text { value } \\
\left(\mathrm{kg} / \mathrm{m}^{3}\right)\end{array}$ & $\begin{array}{c}\text { True } \\
\text { value } \\
\left(\mathrm{kg} / \mathrm{m}^{3}\right)\end{array}$ & $\begin{array}{c}\text { Percentage } \\
\text { error } \\
(\%)\end{array}$ & $\begin{array}{c}\text { Approximate } \\
\text { value } \\
\left(\mathrm{kg} / \mathrm{m}^{3}\right)\end{array}$ & $\begin{array}{c}\text { True } \\
\text { value } \\
\left(\mathrm{kg} / \mathrm{m}^{3}\right)\end{array}$ & $\begin{array}{c}\text { Percentage } \\
\text { error } \\
(\%)\end{array}$ \\
\hline 6 month & 3 & 0.6 & 0.84 & 28.57 & 0.7 & 1.56 & 55.13 & 0.9 & 2.5 & 64.00 \\
\hline \multirow{3}{*}{5 years } & 5 & 0.9 & 1.10 & 18.18 & 2.0 & 2.90 & 31.03 & 2.6 & 3.1 & 16.13 \\
\hline & 10 & 0.6 & 0.80 & 25.00 & 0.6 & 1.45 & 58.62 & 0.9 & 2.4 & 62.50 \\
\hline & 20 & 0.2 & 0.37 & 45.95 & 一 & - & - & 一 & - & - \\
\hline \multirow{5}{*}{50 years } & 10 & 1.2 & 1.19 & 0.84 & 3.1 & 3.50 & 11.43 & 3.5 & 3.4 & 2.94 \\
\hline & 20 & 0.9 & 1.00 & 10.00 & 1.7 & 2.40 & 29.17 & 2.3 & 2.9 & 20.69 \\
\hline & 30 & 0.7 & 0.84 & 16.67 & 0.8 & 1.50 & 46.67 & 1.1 & 2.5 & 56.00 \\
\hline & 40 & 0.5 & 0.67 & 25.37 & 0.4 & 0.90 & 55.56 & - & - & - \\
\hline & 50 & 0.3 & 0.53 & 43.40 & 0.1 & 0.49 & 79.59 & - & - & - \\
\hline
\end{tabular}

Table 3. Percentage errors of no, linear and Freundlich binding of free chloride concentration profiles for $2.5 \mathrm{M}$ exposure conditions.

\begin{tabular}{|c|c|c|c|c|c|c|c|c|c|c|}
\hline \multirow{3}{*}{$\begin{array}{c}\text { Service } \\
\text { life }\end{array}$} & \multirow{3}{*}{$\begin{array}{c}\text { Concrete } \\
\text { cover } \\
(\mathrm{mm})\end{array}$} & \multicolumn{9}{|c|}{$C_{f}$} \\
\hline & & \multicolumn{3}{|c|}{ No binding } & \multicolumn{3}{|c|}{ Linear binding } & \multicolumn{3}{|c|}{ Freundlich binding } \\
\hline & & $\begin{array}{c}\text { Approximate } \\
\text { value } \\
\left(\mathrm{kg} / \mathrm{m}^{3}\right)\end{array}$ & $\begin{array}{c}\text { True } \\
\text { value } \\
\left(\mathrm{kg} / \mathrm{m}^{3}\right)\end{array}$ & $\begin{array}{c}\text { Percentage } \\
\text { error } \\
(\%)\end{array}$ & $\begin{array}{c}\text { Approximate } \\
\text { value } \\
\left(\mathrm{kg} / \mathrm{m}^{3}\right)\end{array}$ & $\begin{array}{c}\text { True } \\
\text { value } \\
\left(\mathrm{kg} / \mathrm{m}^{3}\right)\end{array}$ & $\begin{array}{c}\text { Percentage } \\
\text { error } \\
(\%)\end{array}$ & $\begin{array}{c}\text { Approximate } \\
\text { value } \\
\left(\mathrm{kg} / \mathrm{m}^{3}\right)\end{array}$ & $\begin{array}{c}\text { True } \\
\text { value } \\
\left(\mathrm{kg} / \mathrm{m}^{3}\right)\end{array}$ & $\begin{array}{c}\text { Percentage } \\
\text { error } \\
(\%)\end{array}$ \\
\hline 6 month & 3 & 23 & 53.3 & 56.85 & 24 & 41.7 & 42.45 & 22 & 47.8 & 53.97 \\
\hline \multirow{3}{*}{5 years } & 5 & 62 & 70.0 & 11.43 & 57 & 62.9 & 9.38 & 57 & 58.4 & 2.40 \\
\hline & 10 & 39 & 51.6 & 24.42 & 23 & 39.6 & 41.92 & 21 & 39.5 & 46.84 \\
\hline & 20 & 13 & 23.4 & 44.44 & 4 & 11.0 & 63.64 & - & - & - \\
\hline \multirow{5}{*}{30 years } & 10 & 65 & 73.6 & 11.68 & 59 & 67.7 & 12.85 & 58 & 62.5 & 7.20 \\
\hline & 20 & 44 & 58.1 & 24.27 & 36 & 47.6 & 24.37 & 33 & 45.9 & 28.10 \\
\hline & 30 & 32 & 44.1 & 27.44 & 19 & 31.0 & 38.71 & 17 & 32.6 & 47.85 \\
\hline & 40 & 19 & 32.2 & 40.99 & 9 & 18.7 & 51.87 & - & - & - \\
\hline & 50 & 13 & 22.5 & 42.22 & 2 & 10.3 & 80.58 & - & - & - \\
\hline
\end{tabular}


Table 4. Percentage errors of no, linear and Freundich binding of total chloride concentration profiles for $2.5 \mathrm{M}$ exposure conditions.

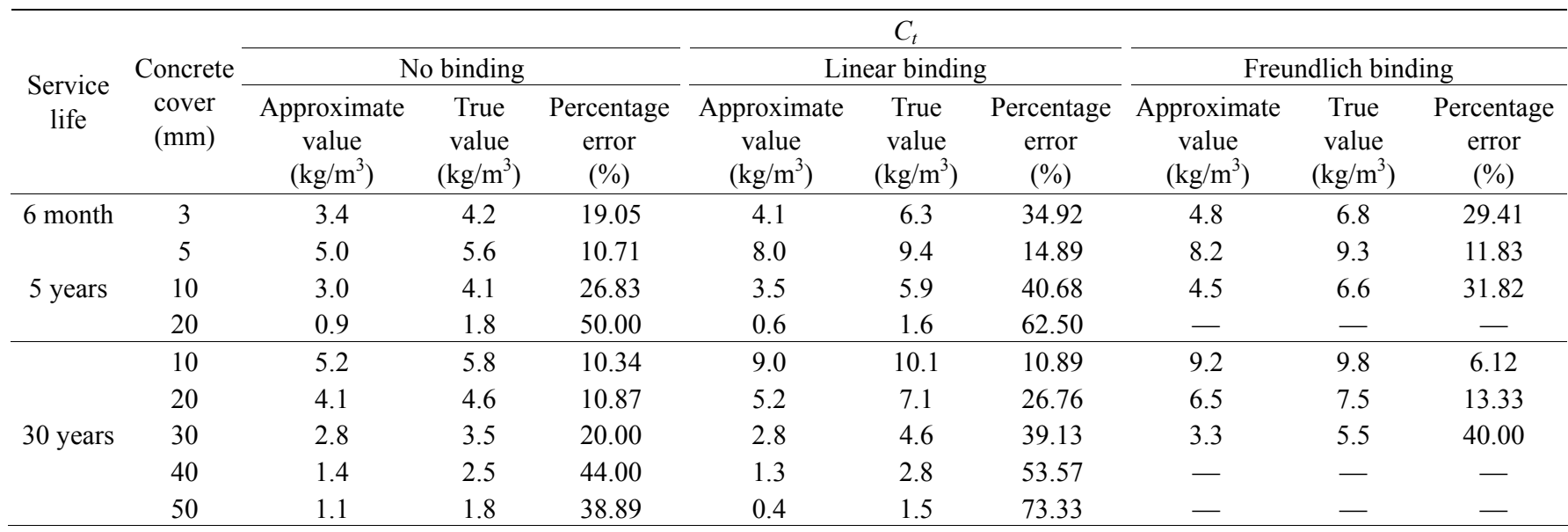

On the basis of the present study results, the calculated chloride profiles are obviously dependent on the supposed binding relationship employed in the theoretical analysis. As a result , the understanding of the binding properties of a given cementitious system and the making use of the suitable binding relationship in theoretical calculation enables the civil engineer to greater good evaluate chloride penetration depths and, accordingly, depassivation time of reinforcing steel bar in concrete.

\section{ACKNOWLEDGMENTS}

The authors gratefully acknowledge the support provided for this research by the National Science Council, Republic of China, under contract No. NSC96-2221-E-157-002.

\section{REFERENCES}

1. Anton, H., Bivens, I., and Davis, S., Calculus, Eighth Edition, John Wiley \& Sons, Inc., New York, NY, USA (2005).

2. Beaudoin, J. J., Ramachandran, V. S., and Feldman, R. F., "Interaction of chloride and C-S-H," Cement and Concrete Research, Vol. 20, No. 5, pp. 875-883 (1990).

3. Birnin-Yauri, U. A. and Glasser, F. P., "Friedel's salt, $\mathrm{Ca}_{2} \mathrm{Al}(\mathrm{OH})_{6}(\mathrm{Cl}$, $\mathrm{OH})-2 \mathrm{H}_{2} \mathrm{O}$ : its solid solutions and their role in chloride binding," Cement and Concrete Research, Vol. 28, No. 12, pp. 1713-1724 (1998).

4. Boddy, A., Bentz, E., Thomas, M. D. A., and Hooton, R. D., "An overview and sensitivity study of a multimechanistic chloride transport model," $\mathrm{Ce}$ ment and Concrete Research, Vol. 29, No. 6, pp. 827-837 (1999).

5. Brebbia, C. A., Telles, J. C., and Wrobl, L. C., Boundary Element Techniques: Theory and Application Engineering, Seringn-Velag, New York (1984).

6. Carslaw, H. S. and Jaeger, J. C., Conduction of Heat in Solids, $2^{\text {nd }}$ Edition, Oxford University Press, New York, USA (1959).

7. Crank, J., The Mathematics of Diffusion, Second Edition, Oxford University Press, Oxford, UK (1975).

8. Delagrave, A., Marchand, J., Ollivier, J.-P., Julien, S., and Hazrati, K., "Chloride binding capacity of various hydrated cement paste system," Advanced Cement Based Materials, Vol. 6, pp. 28-35 (1997).

9. Francy, O. and Francois, R., "Measuring chloride diffusion coefficients from non-steady state diffusion tests," Cement and Concrete Research,
Vol. 28, No. 7, pp. 947-953 (1998).

10. Gebhart, B., Heat Conduction and Mass Diffusion, Mcgraw-Hill Inc., New York, pp. 19-28 (1993).

11. Geiker, M., Nielsen, E. P., and Herfort, D., "Prediction of chloride ingress and binding in cement paste," Material and Structures, Vol. 40, pp. 405 417 (2007).

12. Glass, G. K. and Buenfeld, N. R., "Chloride threshold levels for corrosion induced deterioration of steel in concrete," in: Nilsson, L.-O. and Ollivier, J. P. (Eds.), Chloride Penetration Into Concrete, RILEM, Paris, pp. 429440 (1995).

13. Kane, J. H., Boundary Element Analysis: In Engineering Continuous Mechanism, Prentice Hall, Englewood (1994).

14. Lu, X. Y., Li, C. L., and Zharg, H. X., "Relationship between the free and total chloride diffusivity in concrete," Cement and Concrete Research, Vol. 32, No. 2, pp. 323-326 (2002).

15. Mangat, P. S. and Molloy, B. T., "Chloride binding in concrete containing P F A, gbs or silica fume under sea water exposure," Magazine of concrete Research, Vol. 47, No. 171, pp. 129-141 (1995).

16. Martín-Pérez, B., Zibara, H., Hooton, R. D., and Thomas, M. D. A., "A study of the Effect of chloride binding on service life predictions," $\mathrm{Ce}$ ment and Concrete Research, Vol. 30, No. 8, pp. 1215-1223 (2000).

17. Mejlhede Jensen, O., Freiesleben Hansen, P., Coats, A. M., and Glasser, F. P., "Chloride ingress in cement paste and mortar," Cement and Concrete Research, Vol. 29, No. 9, pp. 1497-1504 (1999).

18. Nielsen, E. P., Herbort, D., and Geiker, M. R., "Binding of chloride and alksalis in portland cement systems," Cement and Concrete Research, Vol. 35, No. 1, pp. 117-123 (2005).

19. Nilsson, L. O., Massat, M., and Tang, L. P., "The effect of non-linear chloride binding on the prediction of chloride penetration into concrete structures," in: V. M. Malhotra (Ed.), Durability of Concrete, ACI, Detroit, pp. 469-486 (1994).

20. Nilsson, L.-O., Poulsen, E., Sandberg, P., Sorensen, H. E., and Klinghoffer, O., "HETEK, Chloride penetration into concrete, state-of-the-art, transport processes, corrosion initiation, test methods and prediction models," The Road Directorate, Report No. 53, Copenhagen (1996).

21. Nilsson, L.-O., Sandberg, P., Poulsen, E., Tang, L. P., Andersen, A., and Frederiksn, M., "HETEK, A system for estimation of chloride ingress into concrete, Theoretical background," The Road Directorate, Report No. 83, Copenhagen (1997).

22. O’Neil, P. V., Advanced Engineering Mathematics, 5th Edition, Brooks/ Cole-Thomson Learning Inc., CA, USA (2003).

23. Poulsen, E. and Mejlbro, L., Diffusion of Chloride in Concrete, Taylor \& Francis, London, UK (2006).

24. Rasheeduzzafar, Ehtesham Hussain, S., and Al-Saadoun, S. S., "Effect of 
cement composition on chloride binding and corrosion of reinforcing steel in concrete," Cement and Concrete Research, Vol. 21, No. 5, pp. 777-794 (1991).

25. Rasheeduzzafar, Ehtesham Hussain, S., and Al-Saadoun, S. S., "Effect of tricalcium aluminate content of cement on chloride binding and corrosion of reinforcing steel in concrete," ACI Materials Journal, Vol. 89, No. 1, pp. 3-12 (1992).

26. Sandberg, P., "Studies of chloride binding in concrete exposed in a marine environment," Cement and Concrete Research, Vol. 29, No. 4, pp. 473-477 (1999)

27. Sergi, G., Yu, S. W., and Page, C. L., "Diffusion of chloride and hydroxyl ions in cementitious materials exposed to a saline environment," Magazine of Concrete Research, Vol. 44, No. 158, pp. 63-69 (1992).

28. Sun, Y. M., Chang, T. P., and Liang, M. T., "Kirchhoff transformation analysis for determining time/depth dependent chloride diffusion coefficient in concrete," Journal of Material Science, Vol. 43, No. 4, pp. 1429-
1437 (2008).

29. Tada, S. and Watanabe, K., "Dynamic determination of sorption isotherm of cement based materials," Cement and Concrete Research, Vol. 35, No. 12, pp. 2271-2277 (2005).

30. Tang, L. P. and Nilsson, L.-O., "Chloride binding capacity and binding isotherms of OPC pastes and mortars," Cement and Concrete Research, Vol. 23, No. 2, pp. 247-253 (1993).

31. Tritthart, J., "Chloride binding in cement II. The influence of the hydroxide concentration in the pore solution of hardened cement paste on chloride binding," Cement and Concrete Research, Vol. 19, No. 5, pp. 683-691 (1989)

32. Wolfram Research, Inc., Mathematica User Manual, Version 3.0, 100 Trade Center Drive, Champaign, IL61820-7237, USA (1997).

33. Yu, S. W., Sergi, G., and Page, C. L., "Ionic diffusion across an interface between chloride-free and chloride-containing cementitious materials," Magazine of Concrete Research, Vol. 45, No. 165, pp. 257-261 (1993). 